\title{
Induction and maintenance of oestradiol and immunoreactive inhibin production with FSH by ovine granulosa cells cultured in serum-free media
}

\author{
B. K. Campbell ${ }^{1 *}$, R. J. Scaramuzzi ${ }^{2 \dagger}$ and R. Webb ${ }^{1}$ \\ ${ }^{1}$ Roslin Institute (Edinburgh), Roslin, Midlothian EH25 9PS, UK; and ${ }^{2}$ CSIRO Division of Animal \\ Production, PO Box 239, Blacktown, NSW, 2148, Australia
}

\begin{abstract}
A serum-free ovine granulosa cell culture system is described that allows the induction of FSH-responsive oestradiol production by undifferentiated cells from small $(<3.5 \mathrm{~mm})$ follicles $(P<0.001)$ and the maintenance of oestradiol production by differentiated cells from large $(\geq 3.5 \mathrm{~mm})$ follicles. Physiological doses of FSH stimulated $(P<0.01)$ proliferation of cultured granulosa cells from both small and large follicles. The synthesis of immunoreactive inhibin and progesterone by granulosa cells from small and large follicles increased $(P<0.01)$ with time of culture, and was not dependent on FSH. Inhibin secretion expressed on a per cell basis was not FSH responsive. Insulin and insulin-like growth factor I (IGF-I), in the presence of FSH, stimulated $(P<0.001)$ cell proliferation and oestradiol and inhibin production by granulosa cells from small and large follicles. There was a significant $(P<0.001)$ interaction between insulin and IGF-I in the stimulation of granulosa cell proliferation and differentiation. Both epidermal growth factor (EGF) and transforming growth factor $\alpha$ (TGF- $\alpha)$ in the presence of FSH stimulated cellular proliferation $(P<0.001)$ in a dose-responsive manner and concomitantly inhibited $(P<0.001)$ oestradiol and inhibin secretion. The development of this granulosa cell culture system will make it possible to study, in vitro, the cascade of events that controls granulosa cell differentiation and ultimately follicle selection in sheep.
\end{abstract}

\section{Introduction}

In sheep, as ovarian follicles grow from the gonadotrophindependent phase (2-3 mm diameter: Scaramuzzi et al., 1993) to preovulatory size $(4-6 \mathrm{~mm})$, the mitotic activity of the granulosa cells declines (Turnbull et al., 1977) and follicles destined to ovulate attain the ability to synthesize large amounts of both oestradiol (Scaramuzzi and Baird, 1977; McNatty et al, 1985; McNeilly et al., 1991) and inhibin (Tsonis et al., 1988; Campbell et al., 1990, 1991a). Both oestradiol and inhibin are almost exclusive products of granulosa cells (Engelhardt et al., 1993; Hinshelwood et al., 1993) and attainment of the ability to synthesize these two hormones is a key indicator of differentiated granulosa cell function. Experiments in vivo have shown that FSH alone can stimulate the growth of large ovarian follicles (Picton et al., 1990) and a marked increase in the ovarian secretion of both oestradiol and inhibin (Campbell ef al., 1993a). Evidence has accumulated indicating that many of these actions of FSH are modulated in the ovary by a number of local factors, including many of the peptide growth factors

\footnotetext{
*Present address: Department of Obstetrics and Gynaecology, University of Edinburgh, Centre for Reproductive Biology, 37 Chalmers St, Edinburgh, EH3 9EW, UK.

${ }^{\dagger}$ Present address: The Royal Veterinary College, University of London, Royal College Street, London, NW1 OTU, UK.

Received 3 May 1995.
}

(Adashi et al., 1985; May et al., 1988; Scaramuzzi and Campbell, 1990). As much of this evidence has been derived from in vitro studies with rodents, their significance to follicle development in large domestic ruminants is not known. However, it has been shown that epidermal growth factor (EGF; Murray et al., 1992), transforming growth factor $\alpha$ (TGF- $\alpha$; Campbell et al., 1994), insulin-like growth factor I (IGF-I; Campbell et al., 1993b) and inhibin (Campbell et al., 1992) can all modulate sheep ovarian follicle development and steroid secretion in vivo. These results provide strong confirmatory evidence that these factors may modulate follicle development in large domestic ruminants. Up until now it has not been possible to extend these findings in vivo to study the molecular basis of these effects in vitro, as the establishment of a physiologically relevant cell culture system for ovarian granulosa cells from large domestic ruminants has proved difficult. While there are numerous reports of granulosa culture systems for both sheep (Campbell, 1989; Webb and McBride, 1990; Monniaux and Pisselet, 1992) and cattle (Skinner and Osteen, 1988; Luck et al., 1990; Langhout et al., 1991; Spicer et al., 1993; Gong et al., 1994), many of the systems reported have the major deficiency that the granulosa cells luteinize spontaneously resulting in a rapid fall in oestradiol and inhibin secretion and a marked increase in progesterone secretion (Skinner and Osteen, 1988; Campbell, 1989; Luck et al., 1990; Webb and McBride, 1990; Langhout ef al., 1991; Meidan et al., 1992; Spicer et al., 
1993; Gong et al., 1994). Furthermore, the proliferative and differentiative responses of cultured granulosa cells to FSH are either lost (Monniaux and Pisselet, 1992) or can only be induced using supra-physiological hormone concentrations (Wrathall and Knight, 1993). Indeed, many of the reports of hormone production by cultured sheep and cattle follicular cells include only data for progesterone secretion (Monniaux and Pisselet, 1992). Alternatively, results are presented for the main follicular hormones without reference to the initial amount of hormone secretion (Wrathall and Knight, 1993; Gong et al., 1994) or from relatively short-term cultures in which cells undergoing early luteinization retain the ability to synthesize some of these hormones (Skinner and Osteen, 1988; Gong et al., 1994). Results from such studies can be misleading because the hormonal 'responses' to treatment may just reflect a change in the rate of luteinization. It is self-evident that to be able to make physiologically relevant inferences from cultured cells, it is essential to have a culture system in which the cells secrete the same hormones and exhibit the same hormonal responses as do cells in vivo.

This study reports the development of a serum-free culture system for granulosa cells that, without the use of attachment factors, allowed the induction of FSH-responsive oestradiol production by undifferentiated granulosa cells from small follicles and the maintenance of oestradiol production by differentiated cells from large follicles. With this culture system, cells from both follicle types are mitotically responsive to FSH. Using this cuiture system, the proliferative and steroidogenic effects of insulin, IGF-I, EGF and TGF- $\alpha$ on cells from small and large follicles were studied.

\section{Materials and Methods}

\section{Materials}

The following were purchased from the Sigma Chemical Co. Ltd, Poole, Dorset: McCoy's 5a media with sodium bicarbonate, Penstrep containing $10000 \mathrm{iu}$ penicillin and $10 \mathrm{mg}$ streptomycin $\mathrm{ml}^{-1}, \mathrm{BSA}$ (tissue culture grade), transferrin, selenium, insulin (bovine), TGF- $\alpha$, neutral red, trypsin, androstenedione and Trypan blue. The following were purchased from GIBCO BRL, Life Technologies Ltd, Paisley, Renfrewshire: Medium 199 (10 times concentrate), Hepes $\left(1 \mathrm{~mol} \mathrm{l}^{-1}\right)$, amphotericin $\left(250 \mu \mathrm{g} \mathrm{ml}^{-1}\right), \quad$ L-glutamine (200 mmol $\left.\mathrm{l}^{-1}\right)$, Dulbecco's PBS without calcium or magnesium $\left(\mathrm{DPBS}^{-}\right.$), Dulbecco's PBS (DPBS ${ }^{+}$). Human recombinant Long R3 IGF-I (LR3-IGF-I, media grade) was purchased from Gropep Pty Ltd (Adelaide, SA). Epidermal growth factor was purchased from Toyoba Co. Ltd (Osaka). The other chemicals used were Analar grade and were obtained from general laboratory suppliers. Ovine FSH (NIDDK-oFSH-S16; bio-

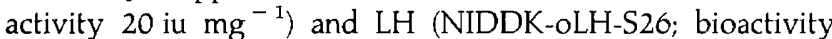

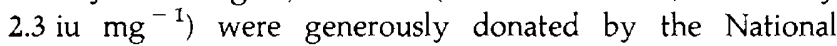
Institute of Arthritis, Diabetes and Digestive and Kidney Diseases (Torrance, CA).

Sterile culture plates, bottles and dishes were obtained from Nunclon (Life Technologies, Paisley); sterile plastic syringes were obtained from Terumo Corp. (Terumo Europe, Leuven); sterile plastic universal containers and centrifuge tubes and
Petri dishes were obtained from Greiner Labortechnik Ltd (Cam, Dursiey, Glos) or Bibby Sterilin Ltd (Stone, Staffs).

\section{Isolation of granulosa cells}

Ovaries were collected directly from animals at the local abattoir and placed immediately in collection medium (Medium 199 containing 20 mmol Hepes $1^{-1}, 100$ kiu penicillin $1^{-1}$, $0.1 \mu \mathrm{g}$ streptomycin $\mathrm{l}^{-1}$ and $1 \mathrm{mg}$ amphotericin (Fungizone) $1^{-1}$ ) at $37^{\circ} \mathrm{C}$. Follicle dissection was carried out in two stages under sterile conditions. Within 2-3 h, approximately 150-200 small (2-3.5 mm diameter) and 20-30 large $(>3.5 \mathrm{~mm}$ diameter) follicles were roughly dissected from the ovaries, and follicles with atretic morphology were discarded. When the desired number of follicles had been obtained, extraneous stromal tissue was removed under a dissecting microscope using watchmakers' forceps. Granulosa cells were isolated from small follicles by hemisecting the follicles in $5 \mathrm{ml} \mathrm{DPBS}^{-}$at $37^{\circ} \mathrm{C}$ and the follicle halves flushed repeatedly up and down the barrel of a $1 \mathrm{ml}$ syringe in a $25 \mathrm{ml}$ Universal container. The thecal shells were then allowed to settle and the resulting granulosa cell suspension was collected. After centrifugation at $800 \mathrm{~g}$ for $10 \mathrm{~min}$, the cell pellets were resuspended in culture medium (McCoy's 5 a containing bicarbonate, $20 \mathrm{mmol}$ Hepes $1^{-1}$, $100 \mathrm{kiu}$ penicillin $1^{-1}, 0.1 \mu \mathrm{g}$ streptomycin $1^{-1}$, $3 \mathrm{mmol}$ L-glutamine $\mathrm{l}^{-1}, 0.1 \% \mathrm{BSA}(\mathrm{w} / \mathrm{v}), 10^{-7} \mathrm{~mol}$ androstenedione $1^{-1}, 2.5 \mathrm{mg}$ transferrin $\mathrm{l}^{-1}, 4 \mu \mathrm{g}$ selenium $\mathrm{l}^{-1}$ ). After a further wash, number of cells and viability was estimated using Trypan blue exclusion. Granulosa cells were isolated from large follicles by aspirating antral fluid using a $1 \mathrm{ml}$ syringe fitted with a 23 gauge needle; the follicles were hemisected in $5 \mathrm{ml}$ of DPBS ${ }^{-}$at $37^{\circ} \mathrm{C}$ and the granulosa cells were gently scraped from the theca with a $10 \mu$ inoculation loop. The resulting granulosa cell suspension was isolated by centrifugation as described for small follicles.

\section{Granulosa cell cultures}

Viable cells (50000-100 000) from either small or large follicles were seeded in a volume of $50 \mu \mathrm{l}$ into pre-prepared and equilibrated 96-well plates containing $200 \mu \mathrm{l}$ of medium with various concentrations and combinations of either insulin ( $1-5000 \mathrm{ng} \mathrm{ml}^{-1}$ ), LR3-IGF-I (I-100 $\mathrm{ng} \mathrm{ml}^{-1}$ ), FSH $\left(0.1-20 \mathrm{ng} \mathrm{ml}^{-1}\right)$, LH $\left(0.01-100 \mathrm{ng} \mathrm{ml}^{-1}\right)$, EGF (0.005$\left.50 \mathrm{ng} \mathrm{ml}^{-1}\right)$ or TGF- $\alpha\left(0.005-50 \mathrm{ng} \mathrm{ml}^{-1}\right)$ replicated in quadruplicate. Cells were cultured in a humidified atmosphere with $3.75 \%$ carbon dioxide in air at $37^{\circ} \mathrm{C}$. Cells were cultured for a total of 6 days and the medium was changed at intervals of $48 \mathrm{~h}$. Disturbance of the cells was minimized by gently removing and replacing only $175 \mu \mathrm{l}$ of media at each change. The spent medium was stored at $-20^{\circ} \mathrm{C}$ before assay.

\section{Estimation of number of granulosa cells}

The number of viable cells per well after 6 days of culture was estimated using the neutral red method (Borenfreund and Puerner, 1984). Briefly, at the end of the culture period spent medium was replaced with $200 \mu$ l of fresh culture medium containing $10 \mu \mathrm{g}$ neutral red, and the plates were incubated for 
$3 \mathrm{~h}$ at $37^{\circ} \mathrm{C}$. After incubation, the neutral red solution was removed and replaced with $200 \mu \mathrm{l}$ of a solution containing $4 \%$ $(\mathrm{w} / \mathrm{v})$ formaldehyde and $1 \%(\mathrm{w} / \mathrm{v})$ calcium chloride (formolcalcium) for 2-3 min. This solution was then removed and $200 \mu \mathrm{l}$ of a solution containing $50 \%(\mathrm{v} / \mathrm{v})$ ethanol and $1 \%(\mathrm{v} / \mathrm{v})$ glacial acetic acid (acetic acid-ethanol) added. Absorbance of this solution was then determined at $540 \mathrm{~nm}$ using a multi-well plate reader. Absorbance was related directly to number of cells by culturing a large number of excess granulosa cells under similar conditions and incubating them with neutral red and isolating them after trypsinization $(0.2 \%(\mathrm{w} / \mathrm{v})$ trypsin and $0.08 \%(\mathrm{w} / \mathrm{v})$ EDTA in DPBS ${ }^{-}$for $\left.20 \mathrm{~min}\right)$. They were then counted using a haemocytometer. These cells were then centrifuged at $800 \mathrm{~g}$ for $10 \mathrm{~min}$ and the cell pellet treated with formol-calcium and acetic acid-ethanol. The resulting solution was then serially diluted in acetic acid-ethanol and $200 \mu \mathrm{l}$ aliquots in quadruplicate were placed in a blank 96-well plate and the absorbance at $540 \mathrm{~nm}$ was determined. The relationship between number of cells and absorbance was linear $(r>0.99)$ and the number of cells per well in the culture plates was estimated from the resulting linear regression equation. The limit of detection of the assay was $2 \times 10^{3}$ cells per well and the coefficients of variation were less than $5 \%$.

\section{Assays}

Concentrations of oestradiol (Webb et al., 1985), inhibin p1-26a subunit (McNeilly et al., 1989) and progesterone (Corrie et al., 1981) in unextracted culture media were determined using radioimmunoassays. The sensitivities of the oestradiol, inhibin and progesterone assays were $1.4 \mathrm{pg} \mathrm{ml}^{-1}$, $35 \mathrm{pg} \mathrm{ml}^{-1}$ and $0.2 \mathrm{ng} \mathrm{ml}^{-1}$, respectively. The intra- and interassay coefficients of variation for oestradiol, inhibin and progesterone were 10.3 and $8.7 \%, 6.0$ and $8.0 \%, 8.3$ and $5.3 \%$, respectively.

\section{Statistical analyses}

Granulosa cells derived from small and large follicles were cultured and analysed separately on the basis of the observation that the diameter of a follicle is closely related to the stage of differentiation of its granulosa cells, and that the sheep antral follicle population can be classified into two physiologically distinct groups on the basis of size. Thus, sheep follicles of $<3.5 \mathrm{~mm}$ diameter contain antral fluid with low oestradiol and inhibin concentrations and mitotically active granulosa cells without $\mathrm{LH}$ receptors, whereas follicles of $>3.5 \mathrm{~mm}$ diameter contain antral fluid with high oestradiol and inhibin concentrations and mitotically inactive granulosa cells with abundant LH receptors (Turnbull et al., 1977; Carson et al., 1979; England et al., 1981; Webb and England, 1982).

All hormone production data were expressed as pg of hormone produced per 1000 cells per $48 \mathrm{~h}$, after correction for the residual amount of media left in the wells when the media was changed at 48 and $96 \mathrm{~h}$. The number of cells used for this calculation was the number of cells after culture for $144 \mathrm{~h}$ and, with the exception of the time course data, only data from 96-144 h of culture are presented. As we have no direct estimates of viable number of cells after culture for $96 \mathrm{~h}$, the time course data have been expressed in terms of pg hormone $\mathrm{ml}^{-1}$ of culture medium for each $48 \mathrm{~h}$ culture period, after correction for carry over. Each experiment was repeated at least three times and the significance of treatment effects was determined by analysis of variance on $\log _{10}$-transformed data, using replicate cultures as blocks. Individual comparisons between treatments were made using the Bonferroni $t$ test.

\section{Results}

\section{Time course of hormone secretion}

Granulosa cells from small follicles secreted little oestradiol during the first $48 \mathrm{~h}$ of culture (Fig. 1). In the absence of FSH, oestradiol production by these cells increased significantly $(P<0.05)$ with time, but in the presence of FSH, there was a marked sequential increase $(P<0.001)$ in oestradiol secretion after culture for 96 and $144 \mathrm{~h}$. In contrast to oestradiol, both inhibin and progesterone secretion by cells from small follicles increased markedly and sequentially with time $(P<0.001)$, regardless of the presence or absence of FSH. Overall, FSH had a weak stimulatory effect on progesterone $(P=0.03)$ and inhibin $(P=0.08)$ production by granulosa cells from small follicles (Fig. 1).

Granulosa cells isolated from large follicles secreted 50-100 times more $(P<0.001)$ oestradiol during the first $48 \mathrm{~h}$ of culture than did cells from small follicles. In the absence of FSH, oestradiol secretion by these cells fell markedly with time $(P<0.01)$, but in the presence of FSH, the amount of oestradiol secretion was maintained (Fig. I). In contrast to oestradiol, both inhibin and progesterone secretion by cells from large follicles increased sequentially with time $(P<0.01)$, regardless of the presence or absence of FSH. Overall, FSH had a stimulatory effect on inhibin $(P<0.01)$ and progesterone $(P<0.01)$ production by granulosa cells from large follicles.

\section{Responses to FSH}

Cultured sheep granulosa cells from both small and large follicles exhibited dose-dependent proliferative and oestrogenic responses to physiological doses of FSH (Fig. 2), but there were marked differences in the responsiveness of cells from small and large follicles to FSH. Cells from small follicles showed a maximal proliferative response at $0.5 \mathrm{ng} \mathrm{FSH} \mathrm{ml}{ }^{-1}(P<0.01)$ and a maximal oestrogenic response at $10 \mathrm{ng}$ oFSH ml ${ }^{-1}$ $(P<0.001)$. In contrast, FSH stimulated $(P<0.01)$ oestradiol production by the cells from large follicles in a dose-dependent manner, without affecting the number of cells, up to a dose of $1 \mathrm{ng} \mathrm{ml}{ }^{-1}$. Higher doses of FSH resulted in an increase $(P<0.05)$ in the number of cells, with a concomitant depression in oestradiol production.

In contrast to oestradiol, inhibin synthesis by cells from small follicles was not responsive to FSH when the results were expressed on a per cell basis (Fig. 2). Similarly, inhibin production by granulosa cells from large follicles was unresponsive to FSH up to $10 \mathrm{ng} \mathrm{FSH} \mathrm{ml}^{-1}$ and higher doses were inhibitory $(P<0.05)$. 

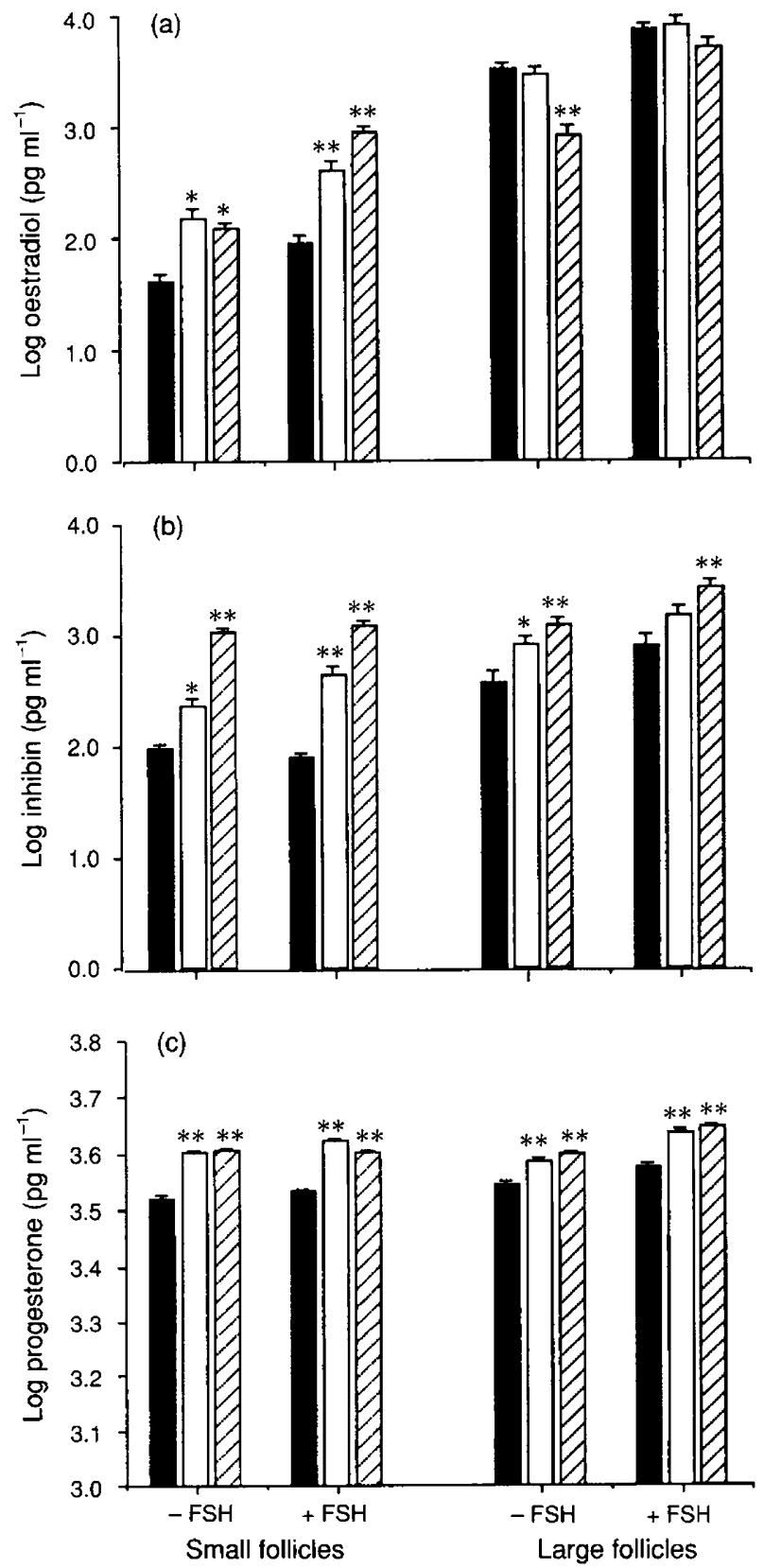

Fig. 1 . The changes in the concentration of (a) oestradiol, (b) inhibin and (c) progesterone in media of cells from small $(<3.5 \mathrm{~mm}$ ) and large $(\geq 3.5 \mathrm{~mm}$ ) sheep ovarian follicles after culture for $0-48 \mathrm{~h}$ ( $\square$ ), 48-96 $\mathrm{h}(\square)$ and 96-144 $\mathrm{h}(\nabla)$ in the presence or absence of $10 \mathrm{ng}$ oFSH-S16 ml-1. Cells were cultured under identical serum-free conditions in the presence of $10 \mathrm{ng}$ insulin $\mathrm{ml}^{-1}$ and $10 \mathrm{ng}$ IGF-I analogue, Long R3 IGF-I ml ${ }^{-1}$. Values are least squares means \pm SEM of three independent replicate cultures. ${ }^{*} P<0.05,{ }^{* *} P<0.01 \mathrm{com}-$ pared with culture for $0-48 \mathrm{~h}$ within each time course (repeated samples ANOVA).

\section{Interaction between insulin and IGF-I in the presence of FSH}

Cell morphology. Both insulin and LR3 IGF-I had a marked effect on the gross morphology of cultured granulosa cells from small follicles. Despite being plated initially as a dispersed monolayer, by the end of the culture period the granulosa cells had formed into dense interconnected clumps. These clumped cells retained the normal spheroidal appearance of granulosa cells, but seemed to be anchored to the culture plate by more elongated spindle-shaped cells, which also projected to adjacent clumps of celis. Although granulosa cells from large follicles tend to be more clumped when they are first plated than do cells from small follicles, high doses of insulin or IGF-I resulted in similar changes in the morphology of cultured granulosa cells from large follicles as those observed for cells from small follicles.

Cell proliferation. After culture for 6 days under serum-free conditions in the presence of FSH, but in the absence of either insulin or IGF, the number of granulosa cells was low $10 \%$ and $31 \%$ of the initial number of cells plated from large and small follicles, respectively; Fig. 3). For granulosa cells from small follicles cultured in the absence of LR3 IGF-I, insulin increased the number of cells in a dose-responsive manner $(P<0.001)$. There was a significant $(P<0.001)$ interaction between insulin and LR3 IGF-I in the stimulation of proliferation of granulosa cells from small follicles (Fig. 3), and the addition of increasing doses of LR3 IGF-I resulted in a flattening of the proliferative dose-response to insulin, so that at the highest dose (100 ng LR3 IGF-I ml $\left.{ }^{-1}\right)$, cells were not responsive $(P=0.9)$ to insulin (Fig. 3). In contrast to granulosa cells from small follicles, the effects of both insulin and LR3 IGF-I on cells from large follicles were mainly restricted to maintaining the number of cells at the number plated, rather than stimulating proliferation (Fig. 3). For granulosa cells from large follicles, cultured in the absence of LR3 IGF-I, insulin increased the number of cells in a doseresponsive manner $(P<0.001)$, and the number of cells was maintained by a dose of $5 \mu \mathrm{g} \mathrm{ml}^{-1}$. There was a significant $(P<0.001)$ interaction between insulin and LR3 IGF-I in the regulation of number of cells from large follicles (Fig. 3). Doses of 1 and $10 \mathrm{ng}$ LR3 IGF-I $\mathrm{ml}^{-1}$ led to maintenance of the number of cells, while the highest dose of $100 \mathrm{ng}$ LR3 IGF-I $\mathrm{ml}^{-1}$ stimulated $(P<0.01)$ the granulosa cells from large follicles to proliferate both in the absence and presence of low doses of insulin (Fig. 3). At the highest dose of LR3 IGF-I, high doses of insulin led to an inhibition of this effect.

Hormone production. Despite a ten-fold difference in the amounts secreted, the effects of both insulin and IGF-I on the pattern of oestradiol and inhibin secretion by cells from small and large follicles were similar. There was a highly significant $(P<0.001)$ interaction between insulin and IGF-I in the stimulation of hormone production by granulosa cells from small and large follicles. Insulin alone stimulated oestradiol and inhibin secretion in a dose-responsive manner $(P<0.001)$, and the supraphysiological dose of $5 \mu \mathrm{g} \mathrm{ml}^{-1}$ resulted in maximal secretion. A dose of $1 \mathrm{ng}$ LR.3 IGF-I ml ${ }^{-1}$ in the absence of, or at low doses of insulin $\left(1-10 \mathrm{ng} \mathrm{ml}^{-1}\right)$, stimulated $(P<0.01)$ oestradiol and inhibin production, but had little effect at higher doses of insulin. A dose of $10 \mathrm{ng}$ LR3 IGF-I ml ${ }^{-1}$ led to a further stimulation $(P<0.05)$ of oestradiol and inhibin production in the absence, or at low doses, of insulin, but tended to be inhibitory at supraphysiological doses of insulin. In contrast, increasing the dose of LR3 IGF-I to $100 \mathrm{ng} \mathrm{ml}^{-1}$ resulted in a marked suppression $(P<0.001)$ of oestradiol and inhibin secretion in the absence of insulin, and cells exposed to this 

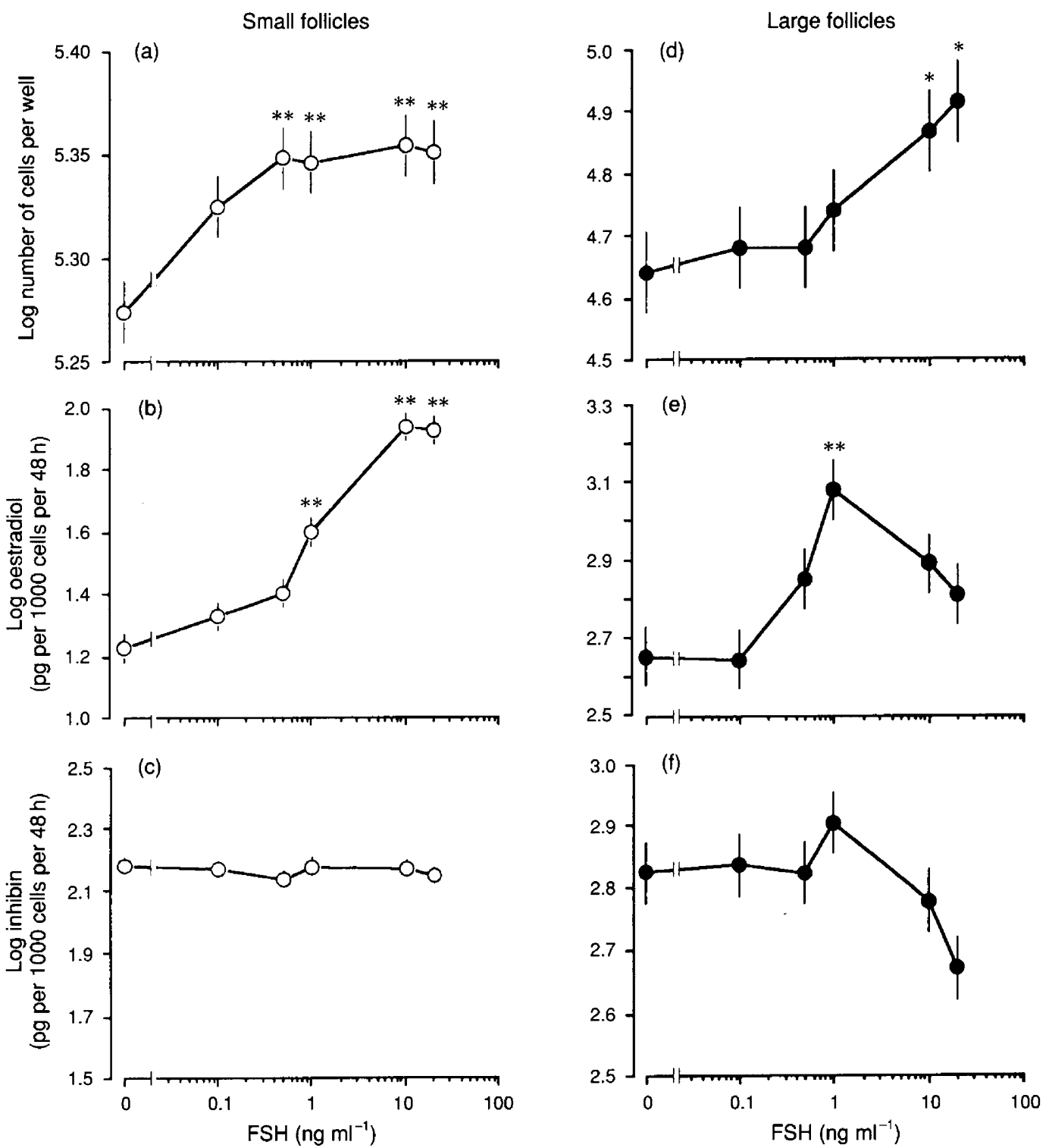

Fig. 2. The effect of oFSH-S16 on ( $a, d)$ number of cells, $(b, e)$ oestradiol and $(c, f)$ inhibin production by sheep granulosa cells isolated from small $(<3.5 \mathrm{~mm} ; \mathrm{a}-\mathrm{c})$ and large $(\geq 3.5 \mathrm{~mm} ; \mathrm{d}-\mathrm{f}$ ) follicles after culture for 6 days under

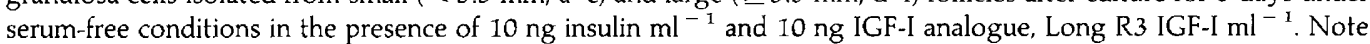
that the oestradiol and inhibin data have been corrected for the effect of number of cells. Values are least squares means \pm SEM of four independent replicate cultures. ${ }^{*} P<0.05,{ }^{* *} P<0.01$ compared with zero dose of FSH (ANOVA with Bonferroni test).

dose of LR3 IGF-I were relatively unresponsive to insulin (Fig. 3). On the basis of the results of this study, a combined dose of $10 \mathrm{ng}$ insulin $\mathrm{ml}^{-1}$ and $10 \mathrm{ng}$ LR3 IGF-I ml ${ }^{-1}$ was chosen for subsequent studies, as these doses are in the physiological range and appear to give the best balance between cell proliferation or maintenance and stimulation of hormone production.

\section{Effect of mitogenic growth factors}

Both EGF and TGF- $\alpha$, in the presence of FSH (10 ng ml ${ }^{-1}$ ), stimulated dose-responsive increases in the proliferation of granulosa cells $(P<0.001)$ from both small and large follicles, and a concomitant inhibition of oestradiol $(P<0.001)$ and inhibin $(P<0.001)$ synthesis (Fig. 4). The presence or absence of FSH had no significant effect on the stimulatory effects of EGF and TGF- $\alpha$ on cellular proliferation, but hormone production was low in the absence of this gonadotrophin (data not shown). Owing to the heterologous nature of the growth factors used, their respective biopotencies were not analysed, but both these growth factors stimulated maximal proliferative responses by granulosa cells from both size classes at doses of $500 \mathrm{pg} \mathrm{ml}{ }^{-1}$. However, granulosa cells from small follicles were more sensitive to these mitogenic growth factors; a dose of $10-20 \mathrm{pg} \mathrm{ml}^{-1}$ was required to stimulate $50 \%$ of the maximum increase in number of cells, compared with a dose of 

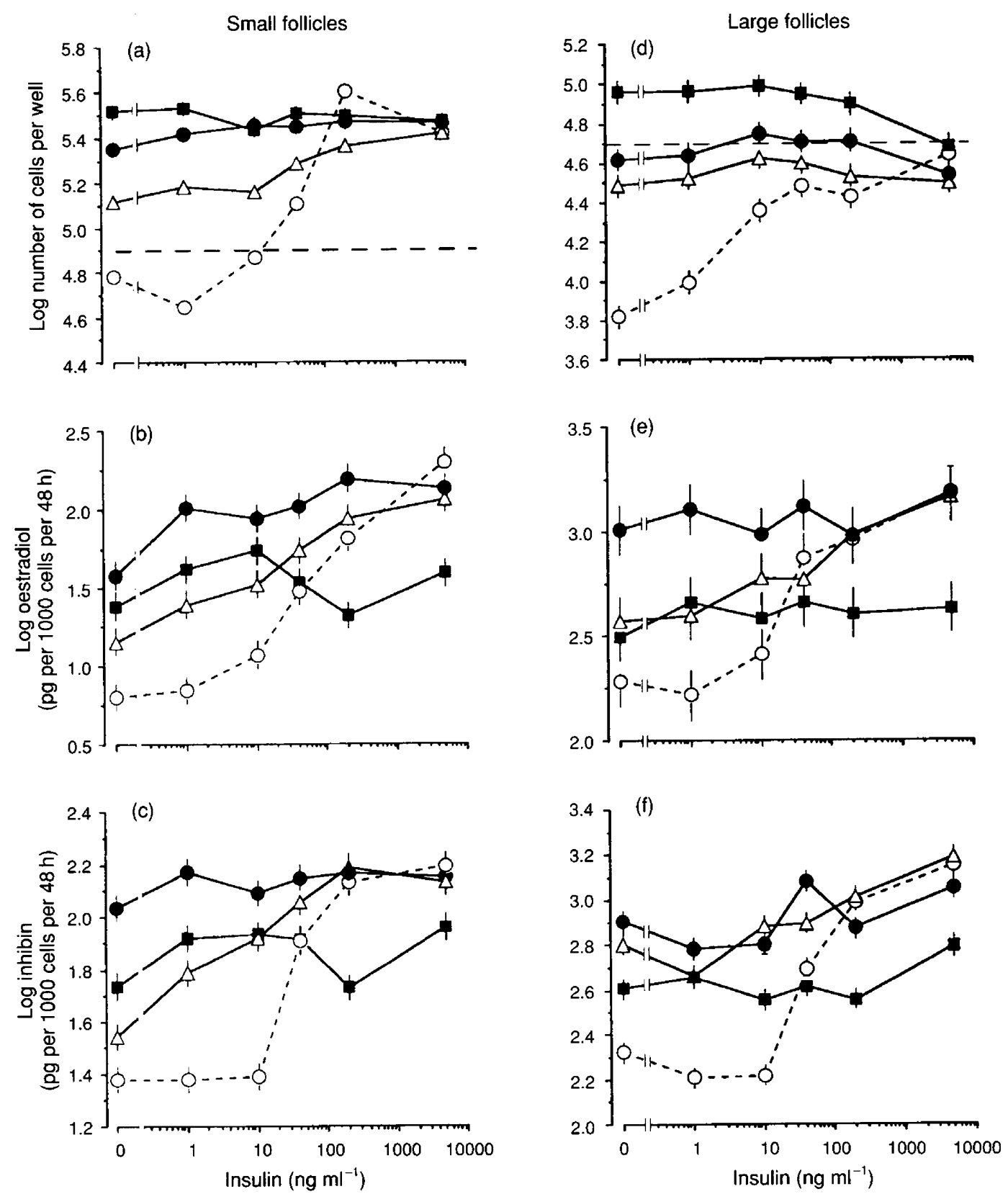

Fig. 3. The effect of insulin on ( $a, d)$ number of cells, (b, e) oestradiol and (c, $f$ ) inhibin production by sheep granulosa cells isolated from small $(<3.5 \mathrm{~mm} ; \mathrm{a}-\mathrm{c})$ and large $(\geq 3.5 \mathrm{~mm}$; $-\mathrm{f})$ follicles after culture for 6 days under serum-free conditions in combination with $0(\mathrm{O}), 1(\triangle), 10(\mathbf{O})$ or $100(\mathbf{a})$ ng IGF-I analogue, Long R3 IGF-I ml $\mathrm{ml}^{-1}$. All cultures were performed in the presence of $10 \mathrm{ng}$ oFSH-S16 $\mathrm{ml}^{-1} .(---)$ indicates the number of cells plated at the start of culture. Note that the oestradiol and inhibin data have been corrected for the effect of number of cells. Values are least squares means \pm SEM of four independent replicate cultures (ANOVA with Bonferroni). For clarity, significance asterisks have been omitted from this figure; the significance of main effects are described in the results.

$60-100 \mathrm{pg} \mathrm{ml}^{-1}$ for granulosa cells from large follicles. In contrast, granulosa cells from both size classes were equally sensitive to the inhibitory effects of these growth factors on hormone production, with the effective $50 \%$ dose being about $5 \mathrm{pg} \mathrm{ml}^{-1}$. Exposure of granulosa cells from both small and large follicles to either EGF or TGF- $\alpha$ resulted in a marked change in the morphology of the cultured cells. Instead of the rather irregular clumping observed with insulin or LR3 IGF-I, the proliferative growth factors stimulated the formation of discrete, condensed spherical balls of cells.

\section{Discussion}

This is the first time that an ovine granulosa cell culture system that allows the induction of FSH-responsive oestradiol 

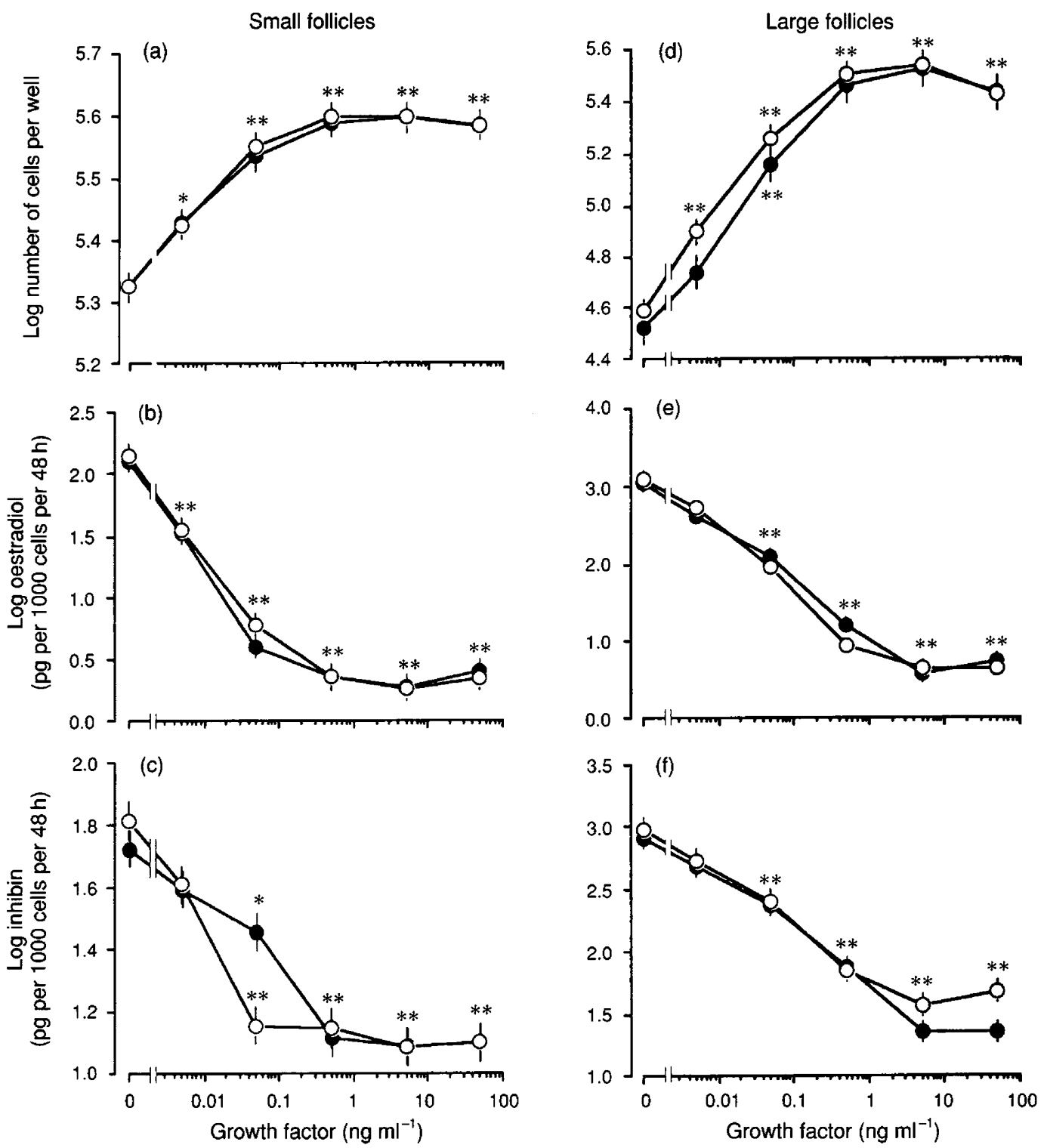

Fig. 4. The effect of epidermal growth factor (EGF) (O) and transforming growth factor (TGF- $\alpha)(0)$ on (a,d) number of cells, (b,e) oestradiol and (c, $f$ ) inhibin production by sheep granulosa cells isolated from small $(<3.5 \mathrm{~mm} ; \mathrm{a}-\mathrm{c})$ and large $(\geq 3.5 \mathrm{~mm} ; \mathrm{d}-\mathrm{f}$ ) follicles after culture for 6 days under serum-free conditions in the presence of $10 \mathrm{ng}$ insulin $\mathrm{ml}^{-1}, 10 \mathrm{ng}$ IGF-I analogue, Long R3 IGF-I ml ${ }^{-1}$ and $10 \mathrm{ng}$ oFSH-SI6 $\mathrm{ml}^{-1}$. Note that the oestradiol and inhibin data have been corrected for the effect of number of cells. Values are least squares means \pm SEM of four independent replicate cultures. ${ }^{*} P<0.05,{ }^{*} P<0.01$ compared with zero dose of growth factor (ANOVA with Bonferroni). Where only one significance asterisk is present at each dose of growth factor, this refers to either EGF or TGF- $\alpha$.

production by undifferentiated cells from small follicles and the maintenance of oestradiol production by differentiated cells from large follicles has been described. In this culture system, physiological doses of FSH can stimulate cellular proliferation, which is apparently a unique finding, as positive proliferative responses of sheep (Monniaux and Pisselet, 1992) or cattle (Gong et al., 1993) granulosa cells to FSH in vitro have not been reported previously. In addition, the proliferative and oestrogenic responses of the granulosa cells depend not only on the amount of FSH stimulation but also on the stage of differentiation of the granulosa cells. Thus, low doses of FSH can stimulate undifferentiated granulosa cells from small follicles to proliferate, whereas higher, but still physiological, doses of FSH can induce the synthesis of oestradiol. Conversely, differentiated granulosa cells from large follicles exposed to low doses of FSH are refractory to the proliferative effects of FSH but sensitive to the oestrogenic effects, whereas higher doses of FSH can stimulate proliferation while concomitantly depressing oestradiol production. These responses to $\mathrm{FSH}$ in vitro parallel closely the changes observed in granulosa cells in vivo during FSH-induced follicle development (McNatty et al., 1985; Picton et al., 1990; Campbell et al., 1993a) and suggest that this granulosa cell culture system is an appropriate physiological model. 
Inhibin, a second major hormone produced by nonluteinized granulosa cells (Luck et al., 1990; Bramley et al., 1992), is also secreted in increasing amounts by granulosa cells from both small and large follicles maintained in serum-free culture. In contrast to oestradiol, inhibin production was not responsive to FSH when the results were expressed on a per cell basis. This observation supports in vivo findings that ovarian inhibin secretion is not acutely responsive to $\mathrm{FSH}$ (Campbell et al., 1991b) and suggests that the increase in ovarian inhibin secretion observed after FSH infusion (Tsonis et al., 1988; Campbell et al., 1993a) mainly reflects an increase in the number of granulosa cells. However, it is clear from both the present experiment and from the findings of Campbell et al. (1991a) that granulosa cells from large follicles secrete more inhibin on a per cell basis than do granulosa cells from small follicles. This finding indicates that this increase in inhibin production is a non-FSH-dependent result of granulosa cell differentiation.

As with inhibin, progesterone secretion by cultured granulosa cells from both size classes increased markedly with time, independently of FSH-stimulation. It is unclear whether this increase in progesterone secretion is simply a reflection of the increase in the steroidogenic potential of the cells as they differentiate or whether it indicates that a proportion of the cells have luteinized. As neither oestradiol nor inhibin are secreted by the ovine corpus luteum (Rodgers et al., 1989), the fact that the cells in this culture system secrete both oestradiol and inhibin indicates that we have at least partially overcome the problem of spontaneous luteinization of granulosa cells in culture. However, it is difficult to determine how much progesterone granulosa cells secrete in vivo, as the theca uses granulosa-derived progesterone as a substrate for androgen synthesis (Dorrington ef al., 1987) and the concentration of progesterone in follicular fluid may therefore not indicate the amount of production. McNatty et al. (1984) reported that progesterone comprises $80 \%$ of the steroid secreted by bovine granulosa cells during short term incubations, and this estimate agrees favourably with the results of the present study that indicate that granulosa cells secrete about ten times more progesterone than oestradiol during the initial $48 \mathrm{~h}$ of culture. Certainly the amount of progesterone secreted by granulosa cells from large follicles stimulated by IGF-I and FSH reported in this experiment is 100 times less than the amount of progesterone secretion by similarly stimulated luteinized sheep granulosa cells (Monniaux and Pisselet, 1992). In addition, in cattle it has been observed that expression of mRNA encoding for cytochrome $\mathrm{P}_{450}$ side chain cleavage is higher in differentiated granulosa cells from the dominant follicle than in undifferentiated cells from small follicles ( $\mathrm{Xu}$ et al., 1995). It is therefore likely that the increase in progesterone secretion by cultured granulosa cells with time mainly reflects an increase in the steroidogenic potential of the cells as they differentiate.

We have hypothesized that the physiological basis of follicle selection is the differential expression of factors that modulate the action of gonadotrophins on follicular cells at key points during the process of follicle development (Campbell et al., 1995). We have used the ovarian autotransplant model to show that intraovarian infusion of both EGF (Murray et al., 1992) and TGF- $\alpha$ (Campbell et al., 1994) in vivo leads to the acute inhibition of ovarian hormone secretion that is associated with induction of atresia in the large follicle population (Radford et al., 1987; Campbell et al., 1994). Alternatively, intraovarian infusion of LR3 IGF-I results in an acute and prolonged stimulation of ovarian steroid secretion (Campbell et al., 1993b), indicating that IGF-I can act in vivo to enhance hormone production by gonadotrophin-dependent follicles. In the present experiment, we used the granulosa cell model system to confirm and extend the results of these studies in vivo. Both EGF and TGF- $\alpha$ stimulated marked increases in proliferation of granulosa cells from both small and large follicles and a concomitant inhibition of oestradiol and inhibin synthesis. In contrast to the proliferative growth factors, both insulin and IGF-I can stimulate granulosa cell proliferation in conjunction with increasing oestradiol and inhibin synthesis (on a per cell basis). While the effects of insulin at supraphysiological doses are probably mediated via the type 1 IGF receptor (Adashi et al., 1985), we have shown that both IGF-I and insulin interact at physiological concentrations to influence both cellular proliferation and hormone production, suggesting that both these metabolic hormones act through their own receptors to stimulate granulosa cell differentiation. The similarity of the responses to the putative intraovarian factors examined in vivo and in vitro provides further evidence that physiologically relevant inferences can be drawn from this granulosa cell culture system. Furthermore, these observations support the hypothesis that the stimulatory action of gonadotrophins can be modulated in the ovary by locally produced factors. The development, for the first time, of a physiological granulosa cell culture system for sheep provides us with a valuable model to further elucidate the mechanism of follicle selection in this species.

The culture system for sheep granulosa cells described in this paper has three key features. The first is the use of a totally serum-free and attachment factor-free culture system. During initial attempts to establish a sheep culture system, it was found that, although cell viability was high when cultures were performed in the presence of serum or with donor calf serum, vitronectin or fibronectin treated plates, oestradiol production by cells cultured under these conditions was low or was not responsive to FSH (Campbell, 1989). The second key feature of this culture system is the inclusion of insulin or IGF-I, as cell viability and hormone production is low in serum-free culture in their absence. As in many serum-free culture systems, insulin alone at supraphysiological concentrations was used initially in this system (Campbell and Scaramuzzi, 1991) and while many of the effects of insulin at these doses are probably mediated via the type 1 IGF receptor (Adashi et al., 1985), the results of this study show that both IGF-I and insulin interact at physiological concentrations to influence both cellular proliferation and hormone production. The LR3 IGF-I analogue used in these studies is ten times more potent than is native IGF-I (Howard and Ford, 1994; B. K. Campbell, R. J. Scaramuzzi and R. Webb, unpublished), presumably owing to its decreased affinity for IGF binding proteins. The final key feature of this culture system is the plating density used. Preliminary studies showed that the induction of oestradiol production by cells from small follicles and the maintenance of oestradiol production by cells from large follicles is critically dependent on cell density, as at low density ( $<20000$ cells per well), cell survival is extremely poor, whereas at high density $(>100000$ 
cells per well), plating efficiencies are high but oestradiol production is low (B. K. Campbell, unpublished). It is possible that this effect of cell density is mediated through the promotion of the clumping of the granulosa cells that is essential for differentiation of the cells through cell-to-cell contact. These three principles have been successfully applied in the development of improved granulosa cell culture systems for both cattle (Guttierez et al., 1994) and pigs (Picton et al., 1994).

In conclusion, this paper reports the development of a physiological culture system for sheep granulosa cells that allows proliferative and differentiative responses to physiological concentrations of FSH in vitro. Using this model system, we have demonstrated that these stimulatory actions of FSH can be enhanced by physiological concentrations of insulin and IGF-I or attenuated by TGF- $\alpha$ and EGF. This cell culture model therefore provides a physiologically relevant model to study the cascade of events that control granulosa cell differentiation and ultimately follicle selection in sheep.

The authors thank D. McBride, G. Baxter and B. M. Gordon for technical assistance. This work was supported by the Australian Wool Corporation (CPB51), European Economic Community (Project 00232, Contract AIR3-CT92-0232), Ministry of Agriculture and Fisheries (MAFF) and Office of Science and Technology (OST).

\section{References}

Adashi EY, Resnick CE, D'ercole AJ, Svoboda ME and Van Wyk JJ (1985) Insulin-like growth factors as intraovarian regulators of granulosa cell growth and function Endocrine Reviews 6 400-420

Borenfreund E and Puerner JA (1984) A simple quantitative procedure using monolayer cultures for cytotoxicity assays (HTD/NR-90) Journal of Tissue Cuilure Methods 9 7-9

Bramley TA, Menzies GS, Baxter G, Webb R and McNeilly AS (1992) Apparent a-inhibin subunit immunoactivity in porcine and ovine luteal extracts is due to interference by cytosolic proteases in the assay Joumal of Endocrinology $134341-352$

Carson RS, Findlay JK, Burger HG and Trounson AO (1979) Gonadotrophin receptors of the ovine ovarian follicle during follicular growth and atresia Biology of Reproduction 21 75-87

Campbell BK (1989). Inhibin oestradiol and progesterone production by ovine granulosa celis in vitro Journal of Reproduction and Fertility Abstract Series 3 Abstract 37

Campbell BK and Scaramuzzi RJ (1991) Induction by FSH of oestradiol and inhibin production by ovine granulosa cells cultured in serum free media containing insulin Journal of Reproduction and Fertility Abstract Series 7 Abstract 15

Campbell BK, Mann GE, McNeilly AS and Baird DT (1990) The pattern of ovarian inhibin estradiol and androstenedione secretion during the estrous cycle in the ewe Endocrinology 127 227-235

Campbell BK, McNeilly AS, Mann GE and Baird DT (1991a) The effect of stage of estrous cycle and follicular maturation on ovarian inhibin production in sheep Biology of Reproduction 44 483-490

Campbell BK, McNeilly AS, Picton HM and Baird DT (1991b) The effect of FSH on inhibin secretion in anoestrous ewes Journal of Reproduction and Fertility 91 501-509

Campbell BK, Tsonis CG, Gordon BM and Scaramuzzi RJ (1992) Ovarian arterial infusion of recombinant human inhibin and bovine follicular fluid inhibits ovarian oestradiol secretion Journal of Reproduction and Fertility Abstract Series 9 Abstract 20

Campbell BK, Gordon BM, Dobson H and Scaramuzzi RJ (1993a) The relative role of $\mathrm{LH}$ and FSH in the growth and maintenance of preovulatory follicles Journal of Reproduction and Fertility Abstract Series 11 Abstract 21

Campbell BK, Scaramuzzi RJ and Webb R (1993b) IGF-I stimulates oestradiol production in sheep, both in vitro and in vivo Journal of Reproduction and Fertility Abstract Series 12 Abstract 23
Campbell BK, Gordon BM and Scaramuzzi RJ (1994) The effect of ovarian arterial infusion of transforming growth factor $\alpha$ on ovarian hormone secretion by ewe with an autotransplanted ovary Journal of Endocrinology $14313-24$

Campbell BK, Scaramuzzi RJ and Webb RW (1995) Control of antral follicle development and selection in sheep and cattle Journal of Reproduction and Fertility Supplement 49 335-350

Corrie JET, Hunter WM and MacPherson JS (1981) A strategy for radioimmunoassay of plasma progesterone with the use of a homologous site ${ }^{125}$ I-labelled radioligand Clinical Chemistry 27 594-599

Dorrington JH, Bendell JJ and Lobb DK (1987) Aromatase activity in granulosa cells: regulation by growth factors Steroids 50 411-421

Engelhardt H, Smith KB, McNeilly AS and Baird DT (1993) Expression of messenger ribonucleic acid for inhibin subunits and ovarian secretion of inhibin and estradiol at various stages of the sheep estrous cycle Biology of Reproduction 49 281-294

England BG, Dahmer MK and Webb R (1981) Relationship between follicular size and antral fluid steroid concentrations at three stages of the estrous cycle in the ewe Biology of Reproduction 24 1068-1075

Gong JG, McBride DM, Bramley TA and Webb RW (1993) Effects of recombinant bovine somatotrophin insulin-like growth factor-I and insulin on the proliferation of bovine granulosa cells in vitro Journal of Endocrinology 139 67-75

Gong JG, McBride DM, Bramley TA and Webb RW (1994) Effects of recombinant bovine somatotrophin insulin-like growth factor-I and insulin on bovine granulosa cell steroidogenesis in vitro Journal of Endocrinology $\mathbf{1 4 3}$ 157-164

Gutierrez CG, Campbell BK, Gong JG and Webb R (1994) An improved long term culture system that maintains aromatase activity in bovine granulosa cells Journal of Reproduction and Fertility Abstract Series 13 Abstract 20

Hinshelwood MM, Corbin CJ, Tsang PCW and Simpson ER (1993) Isolation and characterisation of a complementary deoxyribonucleic acid insert encoding bovine aromatase cytochrome P450 Endocrinology 133 1971-1993

Howard HJ and Ford JJ (1994) Different steroidogenic responses of subpopulations of porcine granulosa cells to insulin-like growth factor (IGF-I) or IGF-I analogs Biology of Reproduction 51 108-115

Langhout DJ, Spicer LJ and Geisert RD (1991) Development of a culture system for bovine granulosa cells: effects of growth hormone, estradiol and gonadotrophins on cell proliferation steroidogenesis and protein synthesis Journal Animal Science $693321-3334$

Luck MR, Rodgers RJ and Findlay JK (1990) Secretion and gene expression of inhibin oxytocin and steroid hormones during the in vitro differentiation of bovine granulosa cells Reproduction Fertility and Development 2 11-25

McNatty KP, Heath DA, Henderson KM, Lun S, Hurst PR, Ellis LM, Montgomery GW, Morrison L and Thurley DC (1984) Some aspects of thecal and granulosa function during follicular development in the bovine ovary Journal of Reproduction and Fertility 72 39-53

McNatty KP, Hudson N, Gibb M, Ball K, Henderson KM, Heath DA, Lun S and Kieboom LE (1985) FSH influences follicle viability oestradiol biosynthesis and ovulation rate in Romney ewes Journal of Reproduction and Fertility $\mathbf{7 5}$ 121-131

McNeilly AS, Swanston IA, Crow W, Tsonis CG and Baird DT (1989) Changes in the plasma concentrations of inhibin throughout the normal sheep oestrous cycle and after the infusion of FSH Journal of Endocrinology 120 295-305

McNeilly AS, Picton HM, Campbell BK and Baird DT (1991) Gonadotrophic control of follicle growth in the ewe Journal of Reproduction and Fertility Supplement 43 177-186

May JV, Frost JP and Schomberg DW (1988) Differential effects of epidermal growth factor somatomedin-C/insulin-like growth factor I and transforming growth factor- $\beta$ on porcine granulosa cell deoxyribonucleic acid synthesis and cell proliferation Endocrinology 123 168-179

Meidan R, Aberdam E and Aflalo L (1992) Steroidogenic enzyme content and progesterone induction by cyclic adenosin $3{ }^{\prime} 5$ '-monophosphate-generating agents and prostaglandin F2 alpha in bovine theca and granulosa cells luteinized in vitro Biology of Reproduction 46 786-792

Monniaux D and Pisselet C (1992) Control of proliferation and differentiation of ovine granulosa cells by insulin-like growth factor-I and follicle-stimulating hormone in vitro Biology of Reproduction 46 109-119

Murray JF, Downing JA, Evans G, Findlay JK and Scaramuzzi RJ (1992) Epidermal growth factor acts directly on the ovary in vivo to inhibit oestradiol- $17 \beta$ and inhibin secretion and enhance progesterone secretion Journal of Endocrinology $137253-264$ 
Picton HM, Tsonis CG and McNeilly AS (1990) FSH causes a time-dependent stimulation of preovulatory follicle growth in the absence of pulsatile LH secretion in ewes chronically treated with gonadotrophin-releasing hormone agonist Journal of Endocrinology 126 297-307

Picton HM, Campbell BK and Hunter MG (1994) Maintenance of aromatase activity in porcine granulosa cells in serum free culture Journal of Reproduction and Fertility Abstract Series 14 Abstract 1

Radford HM, Panaretto BA, Avenell JA and Turnbull KE (1987) Effect of mouse epidermal growth factor on plasma concentrations of FSH, LH and progesterone and on oestrus, ovulation and ovulation rate in Merino ewes Journal of Reproduction and Fertility 80 383-393

Rodgers RJ, Stuchbery SJ and Findlay JK (1989) Inhibin mRNAs in ovine and bovine ovarian follicles and corpora lutea throughout the estrous cycle and gestation Molecular and Cellular Endocrinology 62 95-101

Scaramuzzi RJ and Baird DT (1977) Pulsatile release of luteinizing hormone and the secretion of ovarian steroids in sheep during anestrus Endocrinology 101 1801-1806

Scaramuzzi RJ and Campbell BK (1990) The physiological regulation of ovulation rate in the ewe: a new look at an old problem. In Reproductive Physiology of Merino sheep - Concepts and Consequences pp 7I-84 Eds CM Oldham, GB Martin and IW Purvis. School of Agriculture, The University of Western Australia

Scaramuzzi RJ, Adams NR, Baird DT, Campbell BK, Downing JA, Findlay JK, Henderson KM, Martin GB, McNatty KP, McNeilly AS and Tsonis CG (1993) A model for follicle selection and the determination of ovulation rate in the ewe Reproduction Fertility and Development 5 459-478

Skinner MK and Osteen KG (1988) Development and hormonal regulation of bovine granulosa cell function in the preovulatory follicle Endocrinology 123 $1668-1675$
Spicer LJ, Alpizar E and Echternkamp SE (1993) Effects of insulin, insulin-like growth factor I and gonadotropins on bovine granulosa cell proliferation progesterone production estradiol production and (or) insulin-like growth factor I production in vitro Journal of Animal Science 71 1232-1241

Tsonis CG, McNeilly AS and Baird DT (1988) Inhibin secretion by the sheep ovary during the luteal phase of the oestrous cycle and following stimulation with FSH Journal of Endocrinology 117 283-291

Turnbull KE, Braden AWH and Mattner PE (1977) The pattern of follicular growth and atresia in the ovine ovary Australian Journal of Biological Sciences 30 229-241

Webb R and England BG (1982) Identification of the ovulatory follicle in the ewe: associated changes in follicular size, thecal and granulosa cell luteinizing hormone receptors, antral fluid steroids and circulating hormones during the preovulatory period Endocrinology 116 873-881

Webb R and McBride D (1990) Control of the proliferation of granulosa cells from small ovine follicles Journal of Reproduction and Fertility Supplement 43 229-230

Webb R, Baxter G, McBride D, Nordblom CD and Shaw MPK (1985) The measurement of testosterone and oestradiol-17 $\beta$ using iodinated tracers and incorporating an affinity chromatography extraction procedure Journal of Steroid Biochemistry 23 1043-1051

Wrathall JHM and Knight PG (1993) Production of immunoactive inhibin by bovine granulosa cells in serum-free culture: effects of exogenous steroids and FSH Domestic Animal Endocrinology 10 289-304

$\mathrm{Xu} Z$, Garverick HA, Smith GW, Smith MF, Hamilton SA and Youngquist RS (1995) Expression of messenger RNA encoding cytochrome $P_{450}$ side chain cleavage cytochrome $\mathrm{P}_{450} 17 \alpha$-hydrolylase and cytochrome $\mathrm{P}_{450}$ aromatase in bovine follicles during the first follicular wave Endocrinology 136 981-989 